\title{
THE INFLUENCE OF CULTURE ON THE MOTIVATION FOR THE USE \\ OF SOCIAL MEDIA: A COMPARATIVE STUDY OF TURKISH AND GERMAN HIGH SCHOOL STUDENTS
}

\author{
Selçuk KIRAN ${ }^{1}$, Fatma Göksu DEMİRÇEVİREN ${ }^{2}$
}

\begin{abstract}
This study is an attempt to investigate how cultural contexts determine the use of communication technology by examining the motivations and patterns of using SNS, mainly "Instagram" among teenagers from Turkey and Germany, through a survey. The survey data of total 340 participants were analyzed by using reliability analysis, t-test and Chi-square test. According to the results of the research, Turkish students use social-media with significantly higher motivations of Seeking-Friends and for Entertainment while German students had greater motivation for Seeking-Information. Turkish students have been using Instagram for a longer time and following more accounts in Instagram than German students. While Turkish students use Instagram, LinkedIn and Twitter more, German students use Whatsapp and Tiktok. While Turkish students follow Kim-Kardashian and Kendall-Jenner more, German students follow Cristiano-Ronaldo and Neymar significantly. Turkish students share their posts in InstagramStories and use their accounts as private more than expected compared to German students. Turkish students use their real names and spend more time daily in Instagram compared to German students.
\end{abstract}

Keywords: Social Media, Social Networking Sites, Cultural Difference, Instagram

JEL Classification: D80, M31, L8

\section{KÜLTÜRÜN SOSYAL MEDYA KULLANIM MOTIVASYONU ÜZERINDEKI ETKİSI: TÜRK VE ALMAN LISSE ÖĞRENCILERİ İÇIN KARŞILAŞTIRMALI BİR ÇALIŞMA}

\begin{abstract}
$\ddot{O} \mathbf{z}$
Bu çalışma, Türkiye ve Almanya'daki gençlerin sosyal paylaşım sitelerini, özellikle "Instagram" kullanma nedenlerini ve kalıplarını bir anket yoluyla inceleyerek, kültürel özelliklerin iletişim teknolojisinin kullanımını nasıl etkilediğini incelemeyi amaçlamaktadır. Her iki ülkeden toplam 340 katılımcının katıldığı anket verileri, güvenilirlik analizi, t-testi ve ki-kare testi kullanılarak analiz edilmiştir. Araştırmanın sonuçlarına göre, Türk öğrenciler sosyal medyayı arkadaş aramak ve eğlenmek için önemli ölçüde daha yüksek bir motivasyonla kullanırken, Alman öğrencilerin bilgi arama motivasyonları daha yüksektir. Türk öğrenciler Instagram'ı daha uzun süredir kullanmakta ve Instagram'da Alman öğrencilerden daha fazla hesap takip etmektedir. Türk öğrenciler Instagram, LinkedIn ve Twitter'ı daha çok kullanırken, Alman öğrenciler Whatsapp ve Tiktok'u daha fazla kullanmaktadır. Türk öğrenciler Kim Kardashian ve Kendall Jenner'i daha fazla takip ederken, Alman öğrenciler daha çok Cristiano Ronaldo ve Neymar'ı takip etmektedir. Türk öğrenciler Instagram-Stories'de paylaşımlarını yapmakta ve hesaplarını Alman öğrencilere göre beklenenden daha fazla gizli kullanmaktadır. Türk öğrenciler Alman öğrencilere göre gerçek isimlerini kullanmakta ve her gün Instagram'da daha fazla vakit geçirmektedir.
\end{abstract}

Anahtar Kelimeler: Sosyal Medya, Sosyal Ağ Siteleri, Kültürel Farklılık, Instagram

JEL Sinıflandırması: D80, M31, L8

\footnotetext{
${ }^{1}$ Asst. Prof., Marmara University, Faculty of Business Administration, Management Information Systems, selcuk.kiran@marmara.edu.tr, ORCID: 0000-0001-6088-2701

${ }^{2}$ M.A. Student, Marmara University, Informatics Department, gooksu.de@gmail.com, ORCID: 00000002-2418-6191
} 


\section{Introduction}

With the expansion of the Internet, the use of social media by individuals has increased significantly. Depending on the Internet, social media has become an outlet where individuals can communicate with friends and family from anywhere. According to Safko (2010), social media are defined as "activities, practices and behaviors between communities of people who gather online to share information, knowledge and opinions using conversational media". In other words, social media can be any form of computer-aided communication in which individuals not only create profiles to represent who they are, but also generate and display their own content and interact online with content from their friends or other users (Carr \& Hayes, 2015).

Social Network Sites (SNS) are superset of social media and application platforms. SNS provide information about relationships between individuals, dissolving the previous separation of private and public communication (Hugger, 2010). Nowadays, there are hundreds of social networking sites that use different technologies and bring different cultures together on different interesting topics. SNS generally involve the creation and maintenance of personal and professional online relationships across multiple platforms (Schauer, 2015). Social networking sites are Internet-based services that allow individuals to create profiles that are open to all or part of the users in a restricted system. Links can be shared with others, and thus viewed and reviewed by everyone (Boyd \& Ellison, 2007).

Thus, modern technology has changed the way some people view the world. The invention of mobile phones, laptops, tablets and modern cameras helps bringing the world closer together. Today, these devices are becoming increasingly popular. As technology progresses, so too does access to these devices. Devices that used to be expensive, such as cell phones and cameras, are now reasonably priced, making them accessible to most people. With the further development of these devices, there was also a cultural change that we call visual culture today. Now the question arises, what is meant by visual culture? According to Parsa (2004), visual culture is defined as "a multidisciplinary approach that deals with the social and cultural interpretation of visual experiences and how people define what they see". This cultural phenomenon takes place daily in the social media. If you go to Instagram, for example, you have the opportunity to give your own interpretation of someone else's image, or just to describe what he or she sees.

Today's social media is a perfect example of what and how visual culture works. For example, the visual culture allows the immediate exchange of information to express joy, as most social media networks allow. Today, visual culture is ubiquitous, with billboards, magazines, movies, and television that have taken this culture to new heights. According to Ciochină (2013), "visual culture conveys social contacts, influences personal identity and builds up hierarchies of values". The visual culture has brought social media to new heights and continues to grow daily.

When individuals internalize the norms, rules, and values in a society, they share perceptions of their social environment, resulting in almost automatic processing of what is desirable or should be avoided (Hofstede, 2001; Kim et al., 2011). We often refer to this common perception of the social environment as a culture. Culture determines our perception of ourselves and others, the way we relate to one another, and our communication habits and preferences (Gudykunst \& Nishida, 1986). In view of this, it is surprising that so few studies have used cultural frameworks to study cultural diversity on the World Wide Web. 
Comparing American and Chinese websites, Singh et al. (2003) concluded that "the Web is not a culturally neutral medium, but full of cultural markers that give country-specific websites a unique look and feel local culture". Cultural norms can arise online and are often recognizable in social media profiles.

Several studies (Kim et al., 2011; Cho, 2010) have shown that there are differences in the use of social media between individualistic and collectivist cultures. Collectivist cultures, characterized by family integrity, group membership and strong solidarity, value people's interdependence. Conversely, individuals consider themselves independent (Matsumoto, 2001). In individualistic cultures self-reliance, competition, distance to groups and hedonism are valued (Clark \& Mills, 1979). This was the subject of a comprehensive analysis conducted by Cho (2010). Cho analyzed the content of online profiles on Facebook and Cyworld in the US and Korea (Social Network Site, SNS). The results showed that Cyworld and Facebook users prefer different types of communication styles, reflecting the dimension of individualism and collectivism. While Cyworld users were more popular than Facebook users, they generally did not disclose personal information in the public domain "About Me". Facebook users also used significantly more ego frequencies than Cyworld users, which is consistent with self-created individualistic cultures (Hofstede, 2001). While Facebook users mainly upload self-published photos, more than half of Cyworld users have uploaded fake or anonymous photos.

Individuals in different cultural contexts can use SNS because of different motivations that reflect their prevailing cultural values (Kim et al., 2011). Sheldon and Bryant (2016) found that Instagram users value personal contact less than personal identity and self-promotion. Other motivations include monitoring and knowledge gathering about others, documentation of life events and general serenity. This includes self-promotion and creativity, such as photographic skills. This study found that monitoring was the strongest motivation for using Instagram.

As every year, in collaboration with Hootsuite "We Are Social", a study is published on the state of digitization. This study consists of data and statistics, for Internet-, social media- and mobileusage worldwide (Himmelberg, 2019). In Table 1 analysis published by "We Are Social" is given for Germany and Turkey comparatively.

Table 1: We are Social 2019 Data

\begin{tabular}{|c|c|c|c|c|}
\hline \multirow[b]{2}{*}{ Population } & \multicolumn{2}{|c|}{ Germany (total/per capita) } & \multicolumn{2}{|c|}{ Turkey (total/per capita) } \\
\hline & $\begin{array}{l}82.37 \\
\mathrm{M}\end{array}$ & $\begin{array}{l}\text { Urbanisation: } \\
77 \%\end{array}$ & $\begin{array}{l}82.44 \\
\mathrm{M}\end{array}$ & $\begin{array}{l}\text { Urbanisation: } \\
75 \%\end{array}$ \\
\hline Mobile Subscriptions & $\begin{array}{l}107.8 \\
M\end{array}$ & $\begin{array}{l}\text { vs.Population: } \\
131 \%\end{array}$ & $\begin{array}{l}76.34 \\
\mathrm{M}\end{array}$ & $\begin{array}{l}\text { vs.Population: } \\
93 \%\end{array}$ \\
\hline Internet Users & $\begin{array}{l}79.13 \\
\mathrm{M}\end{array}$ & Penetration: $96 \%$ & $\begin{array}{l}59.36 \\
\mathrm{M}\end{array}$ & Penetration: $72 \%$ \\
\hline $\begin{array}{l}\text { Active Social Media } \\
\text { Users }\end{array}$ & $\begin{array}{l}38.00 \\
\mathrm{M}\end{array}$ & Penetration: $46 \%$ & $\begin{array}{l}52.00 \\
\mathrm{M}\end{array}$ & Penetration: $63 \%$ \\
\hline $\begin{array}{l}\text { Mobile Social Media } \\
\text { Users }\end{array}$ & $\begin{array}{l}30.00 \\
\mathrm{M}\end{array}$ & Penetration: $36 \%$ & $\begin{array}{l}44.00 \\
\mathrm{M}\end{array}$ & Penetration: $53 \%$ \\
\hline
\end{tabular}

Source: WeAreSocial (2019)

The populations of Turkey and Germany are close to each other with about 82 million inhabitants (Table 1). Between these two countries there is only a deviation of around 700 thousand inhabitants. Thus, it allows the comparison of the countries. 
After comparing the two countries, it is clear from the numbers that Germany is recording higher numbers in mobile subscriptions and internet usage. However, in the areas of active social media users and mobile social media users, Turkey is by far ahead.

Instagram is a mobile social network that lets users edit and share photos and videos. In 2010, the first version of Instagram was launched to the world and 25,000 people signed up on the first day (Instagram Info Center, 2010). The Android users had access to the application on April 04, 2012. In 2012, the head of Facebook, Mark Zuckerberg bought Instagram for just under a billion dollars (dpa, 2012). No other photo service was paid for with such a high purchase price. As of June 2018, the mainly mobile photo sharing network has reached 1 billion active users per month (Tankovska, 2018), and it is one of the most popular social networks worldwide. Worldwide, 38 percent of Instagram users are 24 years old or younger (Clement, 2019). Among the leading countries, by number of Instagram users from January 2019, Turkey is in the sixth place and Germany is in the ninth place (Statista, 2019) (Figure 1). In addition, according to Alexa, Instagram is ranked in the 21 st place in Turkey (Alexa, 2020a) and $44^{\text {th }}$ place in Germany (Alexa, 2020b) in the list of top sites which is ordered by the highest combination of visitors and page views.

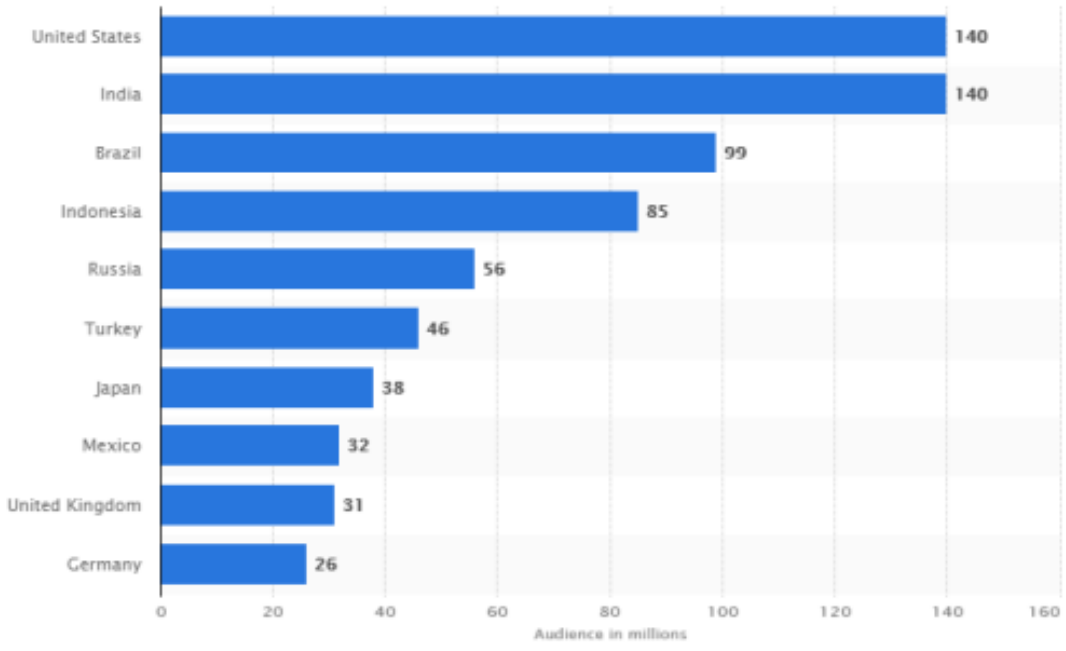

Figure 1: Countries with the most Instagram Users in 2019

Source: https://www.statista.com/statistics/578364/countries-with-most-instagram-users (2019)

On Instagram, users can follow not only their friends but also celebrities and companies. Although the main focus of Instagram is on peers, celebrities have the most followed accounts (Telegraph, 2017). As Brown \& Tiggemann (2016) mentioned in their study "The combination of celebrity images with peer images, presented equally on the same platform, may result in users viewing celebrities more like their peers." Celebrities use Instagram to share their personal and professional life with fans. As of May 2019, the top 7 of the top 10 most followed Instagram users were thin, sporty and attractive female celebrities, Cristiano Ronaldo, Dwayne Johnson and Leo Messi are the only men in the top 10, these three celebrities are also sporty and attractive. At that moment, Cristiano Ronaldo has the most followers on Instagram with more than 165.19 million (Tankovska, 2019b). In the study conducted by Kowalczyk \& Pounders (2016), it is examined how and why consumers use social media to connect with celebrities. The results of a text analysis of the focus groups revealed that consumers follow celebrities on social media to make a career and find out personal information about the celebrities. 
In addition, authenticity and emotional attachment have been identified as favorable aspects for following social media celebrities. An empirical study confirmed that constructive authenticity and emotional attachment positively influence the outcomes of word of mouth and probability of purchase.

The various functions and terminology of Instagram are explained so that no ambiguity arises in the course of the work. On Instagram, pictures and videos are taken or pictures and videos are selected from the photo album of the smartphone. Through existing filters photos could be edited, labeled and uploaded, so easy is the use of this app. After the pictures or videos have been uploaded, they are available to millions of users. They can "like" the pictures / videos, "subscribe" to the user and contact them via message. Among other things one can link his/her account with other social networks and the uploaded videos / pictures appear in the accounts like Facebook or Tumblr. The user must specify a username at the first sign-up. This can contain his/her own name or be a fantasy name. Each name is given only once. Later, the username can be changed. In addition, the user may provide a more detailed description of himself in the user's biography, e.g. age, place of residence, hobbies, profession or a link for a website. Manikonda, Hu \& Kambhampati (2014), analyzed the biographical content of the users in their study. It is interesting to note that most users share their interests in the biography, and it is also common for users to ask other users to follow them.

The user can set whether his/her profile is public or private. Each user has access to the public profiles, which means that all users can view, "like" the pictures / videos, share them (share them in their own profile or forward them to their own friends via message) and comment on them. The profiles that have been set to private are not easily accessible. For this, the user of the private account must accept the subscription request. Only then the other user can see, share and comment the user's pictures / videos. The number of subscribers are the so-called followers. The number of subscribers shows how many users follow. On the main page, Instagram suggests additional user profiles to follow or submit a request based on similar images and hashtags the user uses. Hashtag is defined in the dictionary as a key or keyword. The so-called "hashtags" are there to label pictures. This is done by prefixing the keyword with a hash mark, e.g. \#School. If a user clicks on a hashtag, all the pictures that have the same hashtag will appear. This only applies to users who have their profile public. This increases the likelihood that the uploaded image will be seen and liked by multiple users. At the beginning of August 2016, Instagram introduced the new feature "Instagram Stories" (Instagram Info Center, 2016). Over 400 million people use Instagram stories every day. In other words, they either create their own content for Instagram stories or they consume content from friends, influencers, or company Instagram stories (Firsching, 2018a). Instagram Stories are similar like the well-known Snapchat function: The photos and videos will disappear automatically after 24 hours. However, the user can also delete them earlier. If no other settings are used, followers can see all the stories right when they open the splash screen, or they can block selected followers from seeing the story (Niemetz, 2017). The daily use of Instagram stories continues to increase (Firsching, 2018b).

In sum, the aim/focus of this research is firstly to find out if there are significant differences between the usage and the motivations of use of the social network sites between Turkish and German students and secondly explore details of Instagram accounts and usage habits of the students of both countries. 


\section{Method}

A survey was used to collect data for this study. For the preparation of the questions of this survey a research was done to ascertain which social networks are used by Turkish and German students. Following the determination of these social networks, it was decided that the motivations and de-motivations for the usage of these social networks for the students of both countries can be found and compared through several appropriate questions to be included in the survey. On the other hand, due to the facts that the questionnaire is going to be too long and the students have to complete the whole questionnaire, it was decided to select only one social network to ask more detailed and specific questions related to the social media accounts and usage habits of the students for this research both for exploratory and comparison purposes. For these purposes, Instagram was selected since it is on the top 10 list in both Germany and Turkey (Statista, 2019) and shows an increase in the number of active users. So, this could ensure a more effective study. Besides aiming to reach some exploratory findings and comparisons, considering the purpose of this study, following hypotheses are developed:

$H_{1}$ : There is a significant difference in the social media usage motivations of Turkish and German students.

$\mathrm{H}_{2}$ : There is a significant difference in the duration of Instagram use by German and Turkish students.

$H_{3}$ : There is a significant difference in the number of accounts followed by German and Turkish students on Instagram.

It was decided to conduct the survey with the students aged between 12-19 years. From TurkeyIstanbul 164 students from Marmara Private High School participated. In Germany, the survey was conducted at the Theodor-Heuglin community school near Stuttgart and 176 students participated. Thus, there were a total of 340 participants of the survey. To participate in this survey, respondents were expected to have at least one social media account. The survey consists of four parts: demographic information (? questions), social media usage (1 question), social media usage motivations/de-motivations (? 1-5 Likert questions, 1 open-ended question), and Instagram account and usage habits (? questions). The survey questions were derived and adapted from different sources, (Papacharissi \& Rubin, 2000; Barker \& Ota, 2011; Kim, Sohn, \& Choi, 2011; Barker, 2012; Bradley, 2014; Alhabash \& Ma, 2017; Sheldon, Rauschnabel, Antony, \& Car, 2017) called in to experts' opinions and a pilot study was done with a group of 20 students.

The data was collected using the online tool Google Docs. The most important feature of this tool is that the survey results can be downloaded to PC in Excel format. All data was collected and downloaded from the Internet and analyzed using MS Excel and SPSS programs.

For the study, "independent variables t-test" was found to be appropriate in order to test if the means of two groups are different where homogeneity of the data was considered for the related parameters. The "Cronbach Alpha Reliability Analysis" was performed on Likert-scale data to be used for t-tests where a Cronbach alpha value above 0.70 is sufficient for the reliability of a scale (DeVellis, 2016). 
To determine some relations related to this study, "Chi-Square Independence Test" which is used to examine the relationship between two categorical variables, was inducted where the significance of the Pearson chi-squared value $(\rho)$ less than 0.05 showed that there is a significant relationship between two categorical variables (Yazıcığlu \& Erdoğan, 2004).

\section{Findings}

The survey is expected to show the views of people who share the same opinion as being equivalent. Expressions that can be interpreted differently by different people affect the reliability of the measurement results. Therefore, after completing the survey, the Cronbach Alpha Reliability Analysis performed on Likert-scale data to be used for T-tests. The results of this analysis are shown in Table 2. All alpha values are above 0.70, which means that all variables have passed the reliability analysis and can form scales.

Table 2: Cronbach Alpha Reliability Analysis Results

\begin{tabular}{|l|c|c|}
\hline Motivations for Using Social Networks & Cronbach Alpha & N of Items \\
\hline Seeking Friends & 0.782 & 4 \\
\hline Seeking Social Support & 0.762 & 5 \\
\hline Seeking Information & 0.757 & 6 \\
\hline Seeking Entertainment & 0.716 & 4 \\
\hline Documentation & 0.816 & 5 \\
\hline Coolness & 0.777 & 4 \\
\hline To Spend Time & 0.729 & 5 \\
\hline
\end{tabular}

According to the demographic properties attained from the survey, it was seen that $3.0 \%$ of the participants attended the survey were 12 years, $4.5 \% 13$ years, $14.9 \% 14$ years, $23.9 \% 15$ years, $28.1 \% 16$ years, $14.3 \% 17$ years, $8.7 \% 18$ years and $2.7 \% 19$ years old. The average age of German students who participated in the survey was 14.94 years. The average age of Turkish students was 16.31 years and the average age of the all participants was 15.61 years. Distribution of the attendees by gender and country can be seen in Table 3 .

Table 3: Distribution by gender and country

\begin{tabular}{|l|l|l|l|l|}
\hline & Female & Male & Percent & Total \\
\hline German & $74(21.8 \%)$ & $102(30.0 \%)$ & $51.8 \%$ & 176 \\
\hline Turkish & $84(24.7 \%)$ & $80(23.5 \%)$ & $48.2 \%$ & 164 \\
\hline Total & 158 & 182 & 100 & 340 \\
\hline
\end{tabular}

According to the answers given to the question in which popular social networks the participants have a user account, the distribution is found as summarized in Table 4. 
Table 4: Usage Distribution of Social Networks

\begin{tabular}{|l|l|l|l|l|}
\hline & \multicolumn{3}{|l|}{ Germany } & Turkey \\
\hline & Frequency & Percentage & Frequency & Percentage \\
\hline Instagram & 141 & 80,1 & 149 & 90,9 \\
\hline Facebook & 60 & 34,1 & 48 & 29,3 \\
\hline LinkedIn & 2 & 1,1 & 12 & 7,3 \\
\hline Twitter & 22 & 12,5 & 54 & 32,9 \\
\hline Youtube & 162 & 92,0 & 153 & 93,3 \\
\hline Twitch & 46 & 26,1 & 37 & 22,6 \\
\hline Whatsapp & 25 & 14,2 & 9 & 5,5 \\
\hline Snapchat & 47 & 26,7 & 38 & 23,2 \\
\hline TikTok & 15 & 8,5 & 0 & 0 \\
\hline
\end{tabular}

As mentioned previously, the hypotheses were tested using t-test. Results for three hypotheses are given below:

H1: There is a significant difference in the social media usage motivations of Turkish and German students.

In $\mathrm{H} 1$ the social media usage motivations of Turkish and German students were examined by using five-point likert-scale questions under the headings; "Seeking Friends", "Seeking Social Support", "Seeking Information", "Seeking Entertainment", "Documentation", "Coolness" and to "Spend Time". Descriptive statistics of the dependent variables of two countries are given in Table 5, where: 1 indicates "I strongly agree", 2 "I agree", 3 "I am unsure", 4 "I disagree" and 5 "I strongly disagree". The significance table obtained from the t-tests is given in Table 5. There are two statistics for each dependent variable. The first shows the Levene statistics and the second the Welch statistics. The Levene statistics show whether the variances are distributed homogeneously $(\rho>0.05)$. If the variances are distributed homogeneously, Levene statistics are used, otherwise the following Welch statistics are taken into account.Hata! Başvuru kaynağı bulunamadı. Since the Sig. (2-tailed) values for the motivations; "Seeking Friends (0.00)", "Seeking Information (0.00)" and "Seeking Entertainment (0.048)" is less than 0.05 it is found that, there is a significant difference between German and Turkish students for these motivations. To conclude, H1a, H1c and H1d is accepted while H1b, H1e, H1f, and H1g are rejected.

Table 5: Group statistics and t-test results of Hypothesis 1

\begin{tabular}{|c|c|c|c|c|c|c|}
\hline & Country & $\mathbf{N}$ & Mean & $\begin{array}{l}\text { Std. } \\
\text { Dev. }\end{array}$ & $\begin{array}{l}\text { Sig. } \\
(2- \\
\text { tailed) }\end{array}$ & Hypothesis \\
\hline \multirow{2}{*}{$\begin{array}{l}\text { Seeking } \\
\text { Friends }\end{array}$} & Germany & 176 & 3,28172 & ,916288 & \multirow{2}{*}{, 000} & \multirow{2}{*}{$\begin{array}{c}H_{1 a} \\
\text { accepted }\end{array}$} \\
\hline & Turkey & 164 & 2,83638 & ,998631 & & \\
\hline \multirow{2}{*}{$\begin{array}{l}\text { Seeking Social } \\
\text { Support }\end{array}$} & Germany & 174 & 3,66466 & ,854824 & \multirow{2}{*}{,379 } & \multirow{2}{*}{$\begin{array}{c}H_{l b} \\
\text { rejected }\end{array}$} \\
\hline & Turkey & 163 & 3,58129 &, 881411 & & \\
\hline \multirow{3}{*}{$\begin{array}{l}\text { Seeking } \\
\text { Information }\end{array}$} & Germany & 173 & 2,58150 & ,780391 & \multirow{2}{*}{, 000} & \multirow{2}{*}{$\begin{array}{c}H_{l c} \\
\text { accepted }\end{array}$} \\
\hline & Turkey & 163 & 2,98323 &, 841241 & & \\
\hline & Germany & 173 & 2,45376 & ,890499 &, 033 & \\
\hline
\end{tabular}




\begin{tabular}{|c|c|c|c|c|c|c|}
\hline $\begin{array}{l}\text { Seeking } \\
\text { Entertainment }\end{array}$ & Turkey & 163 & 2,25920 & ,777723 & & $\begin{array}{c}H_{l d} \\
\text { accepted }\end{array}$ \\
\hline & Country & $\mathbf{N}$ & Mean & $\begin{array}{l}\text { Std. } \\
\text { Dev. }\end{array}$ & $\begin{array}{l}\text { Sig. } \\
(2- \\
\text { tailed) }\end{array}$ & Hypothesis \\
\hline \multirow{2}{*}{ Documentation } & Germany & 172 & 3,34302 & ,910888 & \multirow{2}{*}{,444 } & \multirow{2}{*}{$\begin{array}{c}H_{l e} \\
\text { rejected }\end{array}$} \\
\hline & Turkey & 163 & 3,26380 & ,979470 & & \\
\hline \multirow{2}{*}{ Coolness } & Germany & 168 & 3,73264 & ,922696 & \multirow{2}{*}{,249 } & \multirow{2}{*}{$H_{I f}$ rejected } \\
\hline & Turkey & 162 & 3,84928 & ,911856 & & \\
\hline \multirow{2}{*}{ To Spend Time } & Germany & 168 & 2,81488 & 889115 & \multirow{2}{*}{ 480 } & \multirow{2}{*}{$\begin{array}{c}H_{l g} \\
\text { rejected }\end{array}$} \\
\hline & Turkey & 161 & 2,88509 & ,912001 & & \\
\hline
\end{tabular}

Precisely, with a significance level of $5 \%$, it was found that Turkish students use social media with significantly higher motivations for "seeking friends" and "seeking entertainment" while German students had greater motivation for "seeking information". However, for the other motivations; "seeking social support", "documentation", "coolness" and "to spend time" no significant difference between the students from the two countries were found suggesting that they show similar level of motivation to them.

$\mathrm{H}_{2}$ : There is a significant difference in the duration of Instagram use by German and Turkish students.

Descriptive statistics of the dependent variable by two countries and the Sig.(2-tailed) values are shown in Table 6. Since sig.(2-tailed) value is less than 0.05, it can be stated that there is a significant difference between German and Turkish students. After this analysis, the following statement can be said at a significance level of 5\%: The Turkish students have been using Instagram for approximately 1,685 years longer than the German studentss.

$H_{3}:$ There is a significant difference in the number of accounts followed by German and Turkish students on Instagram.

Descriptive statistics of the dependent variable by two countries are shown in Table 6. Since Sig.(2-tailed) is less than 0.05 it can be stated that there is a significant difference between German and Turkish students. After this analysis, the following statement can be said at a significance level of 5\%: Turkish students follow approximately 172 accounts/people more on Instagram than German students.

Table 6: t-test results of Hypothesis 2 and Hypothesis 3

\begin{tabular}{|l|l|l|l|l|l|l|}
\hline & Country & $\mathbf{N}$ & Mean & $\begin{array}{l}\text { Std. } \\
\text { Deviation }\end{array}$ & $\begin{array}{l}\text { Sig.(2- } \\
\text { tailed) }\end{array}$ & Hypothesis \\
\hline $\begin{array}{l}\text { For how long } \\
\text { have you } \\
\text { been using } \\
\text { Instagram? }\end{array}$ & Germany & 132 & 2,36 & 1,291 & & \\
\cline { 2 - 7 } & Turkey & 145 & 4,04 & 1,666 &, 000 & $\mathrm{H}_{2}$ accepted \\
\hline $\begin{array}{l}\text { Number of } \\
\text { Accounts } \\
\text { Followed }\end{array}$ & Germany & 126 & 274,29 & 293,508 & \multirow{2}{*}{, 000} & $\mathrm{H}_{3}$ accepted \\
\cline { 2 - 6 } & Turkey & 142 & 447,13 & 314,894 & & \\
\hline
\end{tabular}


Chi-square test was used to test the relationship between nationality and the social network usage (Table 7). It was found that Turkish students use Instagram, LinkedIn and Twitter more than expected compared to German students and German students use Whatsapp and Tiktok more than expected than Turkish students.

Table 7: Nationality vs Social Networks

\begin{tabular}{|l|l|l|l|l|l|l|}
\hline & \multicolumn{2}{|l|}{ Germany } & \multicolumn{2}{l|}{ Turkey } & & \\
\hline & Count & Expected Count & Count & Expected Count & Pearson & sig. \\
\hline Instagram & 141 & 150,1 & 149 & 139,9 & 7,807 & 0,005 \\
\hline LinkedIn & 2 & 7,2 & 12 & 6,8 & 8,214 & 0,004 \\
\hline Twitter & 22 & 39,3 & 54 & 36,7 & 20,409 & 0,000 \\
\hline Whatsapp & 25 & 17,6 & 9 & 16,4 & 7,167 & 0,007 \\
\hline TikTok & 15 & 7,8 & 0 & 7,2 & 14,622 & 0,000 \\
\hline
\end{tabular}

Chi-square test was used to test the most popular accounts which were followed by Turkish and German students on Instagram. Students were asked to mark the accounts they follow, from the list of the most-followed 8 profiles derived from Trackalytics (2019) which includes; Selena Gomez, Cristiano Ronaldo, Kim Kardashian West, Neymar Jr, Kendall Jenner, Shakira, Justin Timberlake and Leo Messi. The analysis showed that, while Turkish students follow Kim Kardashian West and Kendall Jenner more than expected, German students follow Cristiano Ronaldo and Neymar Junior more than expected (Table 8).

Table 8: Nationality vs popular Instagram accounts followed by the students

\begin{tabular}{|l|l|l|l|l|l|l|}
\hline & \multicolumn{3}{|l|}{ Germany } & Turkey & & \\
\hline & Count & $\begin{array}{l}\text { Expected } \\
\text { Count }\end{array}$ & Count & $\begin{array}{l}\text { Expected } \\
\text { Count }\end{array}$ & Pearson & sig. \\
\hline Cristiano Ronaldo & 44 & 33,7 & 26 & 36,3 & 7,843 & 0,005 \\
\hline Kim Kardashian West & 16 & 22,6 & 31 & 24,4 & 4,371 & 0,037 \\
\hline Neymar Junior & 31 & 24,1 & 19 & 25,9 & 4,596 & 0,032 \\
\hline Kendall Jenner & 11 & 24,1 & 39 & 25,9 & 16,210 & 0,000 \\
\hline
\end{tabular}

Other chi-square results turned out that Turkish students share their posts in the Instagram Story section more and use their accounts as a private account more than expected compared to the German students (sig. values $=0,000$ ). In the examination of whether German and Turkish students use their real first or last names in Instagram accounts, it can be seen that Turkish students use their real first and/or last names more than the expected count compared to the German students (sig. value $=0,000$ ). From the examination of how much time German and Turkish students spend on Instagram in a day, the results showed that the daily time Turkish students spent in Instagram is more than German students (sig. value $=0,007$ ). All of these results are summarized in Table 9. 
Table 9: Miscellaneous Chi-square Results

\begin{tabular}{|c|c|c|c|c|c|c|}
\hline & \multicolumn{2}{|c|}{ Germany } & \multicolumn{2}{|c|}{ Turkey } & \multirow[b]{2}{*}{ Pearson } & \multirow[b]{2}{*}{ Sig. } \\
\hline & Count & $\begin{array}{l}\text { Expected } \\
\text { Count }\end{array}$ & Count & $\begin{array}{l}\text { Expected } \\
\text { Count }\end{array}$ & & \\
\hline $\begin{array}{l}\text { Posting type on } \\
\text { Instagram -Stories }\end{array}$ & 45 & 52.2 & 74 & 60.8 & 16.604 & 0,000 \\
\hline $\begin{array}{l}\text { Using Instagram } \\
\text { Private }\end{array}$ & 87 & 103 & 122 & 106 & 18.973 & 0,000 \\
\hline $\begin{array}{l}\text { Using real names on } \\
\text { Instagram-username }\end{array}$ & 87 & 108.2 & 135 & 113.8 & 38.720 & 0,000 \\
\hline $\begin{array}{l}\text { The time spent on } \\
\text { Instagram }\end{array}$ & 70 & 81.3 & 96 & 84.7 & 7.283 & 0.007 \\
\hline
\end{tabular}

In order to provide an insight for the further studies, we asked the participants of the survey why they thought users deactivated their social media accounts (de-motivations). From 340 participants, 242 students answered the question. After evaluating the answers, the reasons for deactivating social media accounts were summarized under 10 main headings. These main headings and the number of students commenting under these headings from both countries can be seen in Table 10.

Table 10: Reasons for deactivating Social Media Accounts $(n=242)$

\begin{tabular}{|c|c|c|}
\hline . & Germany & Turkey \\
\hline 1. because of the waste of time. & 7 & 34 \\
\hline 2. due to privacy, data protection and security & 27 & 9 \\
\hline 3. due to boredom, no interest or it is not used. & 32 & 19 \\
\hline 4. due to Mobbing. & 12 & 3 \\
\hline $\begin{array}{l}\text { 5. because they don't want others to be informed about their } \\
\text { private lives. }\end{array}$ & 7 & 8 \\
\hline 6. because they think it starts to become an addiction. & 3 & 8 \\
\hline 7. due to pressure of society, family or partner. & 5 & 11 \\
\hline $\begin{array}{l}\text { 8. for a phase in which they don't want to distract their } \\
\text { concentration. }\end{array}$ & 3 & 12 \\
\hline $\begin{array}{l}\text { 9. because of a bad situation that happened to them through } \\
\text { social media. }\end{array}$ & 5 & 11 \\
\hline 10. because they think it's cool. & 5 & 2 \\
\hline 11. other & $?$ & $?$ \\
\hline
\end{tabular}




\section{Discussion and Conclusion}

In sum, the results of this study imply that the three motivations; seeking friends, seeking information and seeking entertainment, show significant differences between the two countries. The differences in the usage of social media have been tested by nationalities and it was found that the Turkish students tend to use social media more to find friends and for entertainment, and German students tend to use social media more often to get information. In addition, there are significant differences between the use of social networks such as Instagram, Twitter, LinkedIn, Whatsapp and Tiktok. According to the social networks used, analysis shows that more Turkish students have Instagram, Twitter and LinkedIn accounts and the German students have more WhatsApp and Tiktok accounts than the Turkish students. The reason for the lack of usage of Twitter in Germany could be grounded to the German language and the restriction of the characters that can be used in a tweet. The German language is a very descriptive language and the length of the German words also makes it difficult to create expressive, appealing tweets. For this reason, Twitter could be used more passively in Germany. In addition, the minor usage of LinkedIn can stand to the reason of a German equivalent site of LinkedIn named XING. It is more popular than LinkedIn in Germany and "about every fifth worker in Germany, Austria and Switzerland is now an XING member” (Schenk, 2019).

Under the question of how long the Turkish and German students have been using Instagram, it came to the conclusion that the Turkish students have been using Instagram for a longer time than the German students. However, the average age of the German students (14.94) participated in the survey is smaller than the average age of the Turkish student (16.31) participated in the survey. Within this context, we can say that the average age of Turkish and German students started using Instagram is very close to each other.

When we look at the differences of the use of Instagram by the students of both countries, there are significant differences between two countries; in using their profiles as private or public, at the preference of the posting type they share their pictures or videos (Story/Feed), the length of daily time they spend on Instagram, the use of their real names as their username (Table 9), the celebrities they follow (Table 8) and the number of accounts they follow (Table 6). The results of the analyses show that Turkish students follow more accounts on Instagram than the German students which we can associate to the daily time they spend on Instagram. As Turkish students spend more time on Instagram, they can monitor more profiles and posts, so they follow more accounts.

Another result of the analysis on Instagram shows that the Germans follow Cristiano Ronaldo and Neymar Junior more than the Turks, and the Turks follow Kim Kardashian West and Kendall Jenner more than the Germans. The reason why German students follow the football stars more compared to the Turkish students could be that today football is by far the most popular sport in Germany (Statista, Beliebteste Sportarten in Deutschland, 2019) and especially the players of the German national team enjoy hero's status. Of course, this rises and falls depending the successes. Similar with many other countries in which football enjoys a similarly high ranking, Germany has a well-structured organization with the DFB (German Football Association), which is responsible for planning and drafting all tournaments and raising awareness of the importance of sport and the stadiums are always well filled unlike other big leagues. 
According to the results of the analysis that examined students' posting type on Instagram, it was found that Turkish students share their posts more in the Story-Section of Instagram compared to German students. In the answers to the open-ended question at the survey "why users disable their social media accounts", the Turkish students responded choosing "pressure of society, family or the partner" as a reason in contrast to the German students. One can therefore assume that they share more in the Instagram Story Section than the German students because on Instagram-Stories a function for hiding the posts from the desired users is possible. Another analysis supporting this situation is the test of whether German and Turkish students use their Instagram accounts as private or public for all other users. According to the test results, it was found that Turkish students use their accounts in private-option more than the German students so that only the preferred users/their followers can see their profiles.

As a result of another analysis of whether or not the students use their real first and/or last names in their Instagram user names, it was found that Turkish students used their real first and/or last names more frequently than German students. Schenk explained this in 2019 as "There is a growing trend for Germans to use fake names or abbreviations instead of their real names. Another example is a strong hesitation for signing up to or liking social media pages as German people do not want to give out too much information". Moreover, when asked why users deactivate their social media accounts, German students often mentioned the reasons for privacy and security compared to Turkish students. Based on the results of these analyses, it can be said that privacy and security are more important for the use of social media for German students than for Turkish students. According to the results of the tests for the time German and Turkish students spend using Instagram in a day, it is found that the Turkish students spend more time on Instagram than the German students which corresponds to the arguments in the literature review.

This study had several limitations. Even though social media and social networking platforms are used by young adults at most, the results cannot be transmitted to the entire population of social media users. Additionally, the second part of the survey was only filled by the students who have an Instagram account. Although $80.1 \%$ of German participants and $90.9 \%$ of Turkish participants were Instagram users, a larger sample would allow a more sophisticated statistical analysis.

Lastly, the survey was conducted in Germany at Theodor Heuglin School which is a Community School and in Turkey at Marmara Private High School. Since Marmara High School is a private school it has an annual tuition which is over 40,000 Turkish Lira (nearly 6,000 Euro). Since the tuition fee is very high compared to the average income in Turkey, we can assume that students of the Marmara Private High School are in different social status compared to the students studying in a state high school. Therefore, future studies could repeat the survey in different cities of the country and with different types of schools.

\section{References}

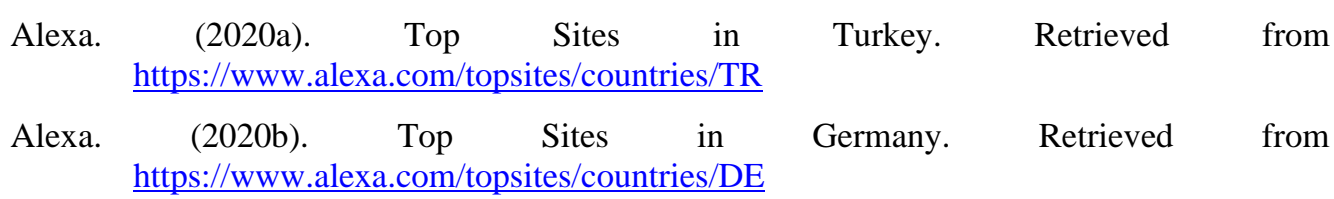


Alhabash, S., \& Ma, M. (2017). A Tale of Four Platforms: Motivations and Uses of Facebook, Twitter, Instagram, and Snapchat Among College Students? Social Media + Society.

Barker, V. (2012). A Generational Comparison of Social Networking Site Use: The Influence of Age and Social Identity. The International Journal of Aging and Human Development, 163-187.

Barker, V., \& Ota, H. (2011). Mixi Diary versus Facebook Photos: Social Networking Site use among Japanese and Caucasian American Females. Journal of Intercultural Communication Research, 39-63.

Boyd, D. M., \& Ellison, N. B. (2007). Social Network Sites: Definition, History, and Scholarship. Journal of Computer-Mediated Communication, 210-230.

Bradley, P. (2014). Instagram: Why do we Post? Southern Illinois University at Edwardsville.

Brown, Z., \& Tiggemann, M. (2016). Attractive celebrity and peer images on Instagram: Effect on women's mood and body image. Body Image, 37-43.

Carr, C. T., \& Hayes, R. A. (2015). Social Media: Defining, Developing, and Divining. Atlantic Journal of Communication.

Cho, S. (2010). Cross-cultural comparison of Korean and American social network sites: exploring cultural differences in social relationships and self-presentation.

Ciochină, R. (2013). Revisiting Visual Culture. Analele Universităţii Spiru Haret. Seria Jurnalism, 60-67.

Clark , M., \& Mills, J. (1979). Interpersonal attraction in exchange and communal relationships. Journal of Personality and Social Psychology, 12-24.

Clement. (2019). Instagram: age distribution of global audiences 2019| Statistic. Retrieved from Statista: https://www.statista.com/statistics/325587/instagram-global-age-group/

DeVellis, R. (2016). Scale Development: Theory and Applications.

dpa. (09. 04 2012). Die Zeit. Von https://www.zeit.de/wirtschaft/unternehmen/201204/facebook-instagram-uebernahme abgerufen

Firsching, J. (2018, August 13). Mehr Posts \& weniger Interaktion auf Facebook = Stories sind der neue Feed. Retrieved from FUTUREBIZ: http://www.futurebiz.de/artikel/mehrposts-weniger-interaktion-auf-facebook-stories-sind-der-neue-feed/

Firsching, J. (2018, November 14). Instagram Stories: Wie Unternehmen Instagram Stories einsetzen sollten. Retrieved from http://www.futurebiz.de/artikel/instagram-stories-tipps-unternehmen/

Gudykunst, W., \& Nishida, T. (1986). Attributional Confidence in Low- and High-Context Cultures. Human Communication Research, 525-549.

Himmelberg, C. (2019, Jan 31). We Are Social Deutschland. Retrieved from wearesocial: https://wearesocial.com/de/blog/2019/01/digital-2019-deutschlands-digitalesverhalten

Hofstede, G. (2001). Culture's Consequences: Comparing Values, Behaviors, Institutions and Organizations Across Nations. SAGE Publications.

Hugger, K. U. (2010). Digitale Jugendkulturen. Wiesbaden: VS Verlag für Sozialwissenschaften.

Instagram Info Center. (2010). Retrieved from https://instagrampress.com/blog/2010/10/06/instagram-launches-2/

Instagram Info Center. (2016). Introducing Instagram Stories. Retrieved from Instagram-Press: https://instagram-press.com/blog/2016/08/02/introducing-instagram-stories/

Instagram: age distribution of global audiences 2019 | Statistic. (2019). Retrieved from Statista: https://www.statista.com/statistics/325587/instagram-global-age-group/ 
Kim, Y., Sohn, D., \& Choi, S. (2011). Cultural difference in motivations for using social network sites: A comparative study of American and Korean college students. Computers in Human Behavior, 365-372.

Kowalczyk, C., \& Pounders, K. (2016). Transforming celebrities through social media: the role of authenticity and emotional attachment. Journal of Product \& Brand Management.

Manikonda , L., Hu, Y., \& Kambhampati, S. (2014). Analyzing User Activities, Demographics, Social Network Structure and User-Generated Content on Instagram.

Matsumoto, D. (2001). The Handbook of Culture and Psychology. Oxford University Press.

Niemetz, K. (2017, 06 23). Was ist "Instagram Stories"? Einfach erklärt - CHIP. Retrieved from https://praxistipps.chip.de/was-ist-instagram-stories-einfach-erklaert_93709

Papacharissi, Z., \& Rubin, A. (2000). Predictors of Internet Use. Journal of Broadcasting \& Electronic Media, 175-196.

Parsa, A. F. (2004). Imgenin Gücü ve Görsel Kültürün Yükselişi .

Safko , L. (2010). The Social Media Bible: Tactics, Tools, and Strategies for Business Success. John Wiley \& Sons.

Schauer, P. (2015, June 28). 5 Biggest Differences between Social Media and Social Networking | Social Media Today. Retrieved from Social Media Today: https://www.socialmediatoday.com/social-business/peteschauer/2015-06-28/5biggest-differences-between-social-media-and-social

Schenk, K. (2019, June 05). Social Media in Germany. Retrieved from ExtraDigital Ltd: https://www.extradigital.co.uk/articles/social-media/german-social-media-use.html

Sheldon, P., \& Bryant, K. (2016). Instagram: Motives for its use and relationship to narcissism and contextual age. Computers in Human Behavior, 89-97.

Sheldon, P., Rauschnabel, P., Antony, M., \& Car, S. (2017). A cross-cultural comparison of Croatian and American social network sites: Exploring cultural differences in motives for Instagram use | Elsevier Enhanced Reader. Computers in Human Behavior, 643 651.

Singh, N., Zhao, H., \& Hu, X. (2003). Cultural Adaptation on the Web: A Study of American Companies' Domestic and Chinese Websites. Journal of Global Information Management (JGIM), 63-80.

Statista. (2019). Beliebteste Sportarten in Deutschland. Retrieved from Statista: https://de.statista.com/statistik/daten/studie/171072/umfrage/sportarten-fuer-diebesonderes-interesse-besteht/

Statista. (2019). Leading countries based on number of Instagram users as of October 2019. Retrieved from https://www.statista.com/statistics/578364/countries-with-mostinstagram-users/

Tankovska, H. (2018, June). Statista. Retrieved from https://www.statista.com/statistics/253577/number-of-monthly-active-instagramusers/

Tankovska, H. (2019). Most followed Instagram accounts 2019. Retrieved from Statista: https://www.statista.com/statistics/421169/most-followers-instagram/

Telegraph, T. (2017). Most popular Instagram accounts - in pictures. Retrieved from https://www.telegraph.co.uk/technology/2015/12/14/the-ten-most-popular-instagramaccounts-in-pictures/nicki-minaj-instagram-account/

Trackalytics. (2019). The Most Followed Instagram Profiles | Trackalytics. Retrieved from https://www.trackalytics.com/the-most-followed-instagram-profiles/page/1/

Yazıcıŏ̆lu, Y., \& Erdoğan, S. (2004). SPSS Uygulamalı BÍLIMSEL ARAŞTIRMA YÖNTEMLERI. Ankara : Detay Yayıncılık. 